\title{
Common Attributes of Outstanding College EFL Teachers' Teaching
}

\author{
Ching-ning Chien \\ Chung Yuan Christian University, Taiwan
}

\begin{abstract}
This study looks into three outstanding EFL teachers' classrooms in a Taiwan university. They have proven to be effective in achieving results which are appreciated by their students. The study aimed to isolate some characteristics shared by the teachers. Students were surveyed via interviews to gain insight into their perceptions of learning experiences. Teachers were also observed and interviewed about how they helped students learn. A paired t-test indicated that students significantly improved their English proficiency. This study analyzed information collected from both students and teachers with the goal of finding common teaching attributes that left students satisfied with their learning experience. Finally, it revealed that there was evidence of emotional investment, stimulation, and innovation in all three classrooms.
\end{abstract}

Index Terms - emotional investment, innovation, outstanding teachers, stimulation, students' perspective

\section{INTRODUCTION}

When looking at Taiwanese students' English competency, a clearly skewed and bimodal distribution emerges, with each mode representing two extremes - either very good or very poor. This phenomenon reflects upon primary school and high school students from city to countryside and extends on to college (Lo, 2005; San, 2005). For example, more than $10 \%$ of the total number of students received a score of zero on the guided writing section of their English exam in the National Joint College Entrance Exam (Wang, 2009; Wang, 2010). According to a survey of 4,250 freshman non-English majors (Chien, 2008), across the board, students recognized the importance of English for the purposes of their current academic pursuits and future professional careers. They also expressed a desire to be able to communicate with foreigners in English. With the career and relational motivations, students should be spurred to make effort for improvement over the university Freshman English course of time. However, quite a portion of university students feel their English ability keeps declining year after year from the time they enter university, compared with the time in which they studied English more hours in high school. Previous studies have also shown that students' expectations of English programs in university have not been satisfied (Chia, et al. 1999; Hsieh, et al. 1988; Kuo, 1987; Kuo, et al. 1990; Wang, 2003; Yang, 1985). The complaint has been clearly shown from Student Evaluation of Teaching reports (SET). After having put in so much effort and time working with students, many teachers are disappointed by the reactions and comments on the SET. Therefore, teachers who teach non-English majors often experience great disappointment and frustration as much as their students do.

There has been plenty of research regarding foreign language learning and teaching to help foreign language learners (e.g., Brown, 2007; Cohen \& Weaver, 2005; O'Malley \& Chamot, 1990; Oxford, 2003). Perhaps the most basic instructional objective in a foreign language class is to send students away with at least as favorable an attitude toward learning the language as they had when they first arrived in the classroom (Gunderson \& Johnson, 1980). What students can learn from the teachers is more important than what the teachers teach them. Then, how can teachers help students learn? There is no doubt that teaching methods and practices, teaching materials and others all contribute to successful teaching, but teachers themselves as the irreplaceable facilitators play the most important role for their students' learning achievement. This study chose three model teachers who teach English as a foreign language (EFL) to look into. Model teacher is a cultural phenomenon in which parents and students often assume that they are the best and they are held examples for other teachers. The study aimed to identify some characteristics shared by the EFL teachers. Probably the findings about their practices in the context can be shared with other teachers to modify English teachers' teaching and as a result, better assist student learning.

\section{LITERATURE REVIEW}

Many case studies and profiles of outstanding college teachers have been reported in the past decade. Most of these studies focus on teachers who have been selected as "outstanding", "exemplary", "effective", or "successful" (Hativa, Barak, \& Simhi, 2001; Magno \& Sembrano, 2007; Young \& Shaw, 1999). In many these studies, the superlatives used to describe the teachers profiled were not defined, which can make it difficult to compare results across studies. For example, Hative, Barak, and Simhi (2001) used both "exemplary" and "outstanding" to describe teachers who were highly rated by their students through standardized student evaluation forms. Young and Shaw (1999) used the term "effective" to describe teachers who were selected by student surveys as being "effective", without any measure of 
actual learning. In Bain's What the Best College Teachers Do (2004, p. 5), the "best" was defined as "success in helping...students learn in ways that [make] a sustained, substantial, and positive influence on how...students think, act, and feel". Allan, Clarke, and Jopling (2009, p. 364) described the different interpretations of "teacher effectiveness", finally settling on a definition based on student achievement. To determine the accuracy of administrators in selecting "effective" teachers, Strong, Gargani, and Hacifazlioglu (2011) compared student achievement tests to the school administrators' ratings of the same teachers.

However, the students' perceptions of their teachers cannot be overemphasized in education because they provide rich information for understanding students' cognition and classroom processes (Knight \& Waxman, 1991). The students' perceptions enable researchers and teachers to appreciate students' thought processes (Tuan, Chang, Wang, \& Treagust, 2000). Learning takes place when students feel like entrusting themselves to their teacher's teaching, willing to actively participate in learning activities which might be something new or challenging to them. Although substantial studies asserted the effectiveness of specific teaching methods and practices, there has been a total lack of research on EFL learners' perceptions of their own learning experiences in the existing theories on second/foreign language acquisition, especially within the EFL environments.

This study aims to discover a basic underlying theme or principle that may enhance teaching effectiveness among university English teachers in a classroom, and to answer the question of what common thread unites different teachers who are favored by their students. Although this study focuses on College English teaching and learning in an EFL context, there is no reason to expect that the results that are produced here are limited in applicability to the field of language teaching (Millis \& Rhem, 2010). The generalizability of findings may be more dependent on time, place, and student demographics than on the particularities of specific subject matters. With this in mind, this study has one important research aim which is to investigate what model teacher qualities or characteristics are demonstrated in the classrooms and if any commonalities exist in the participating outstanding teachers.

\section{Methodology}

First of all, the researcher had to identify the three model participating teachers from 50 60 teachers of total 75 80 classes in the university. Secondly, she had to randomly select the representative, sampled students from the 7 classes the model teachers were teaching. In order to achieve the study goals, information pertaining to the teachers' teaching styles was obtained through students' interviews by audiotape recordings as well as teacher interviews by filming videotapes. The teacher interviews and student interviews were transcribed and then coded. To get a complete picture, the researcher took notes during the classroom observations, wrote analytic memos and contact summaries after watching each class video clip for each teacher and each student. Therefore the triangulation of methods was achieved by comparing the students' perspective with the teachers' perspective and the observer's perspective of the teaching styles in the classroom. In addition, to substantiate the teachers' teaching effectiveness, all the participating students were administered the MEPT pre-test at the beginning of the second semester and the same test (post-test) at the end of the second semester. A paired t-test was used to assess how much progress these students had achieved in the post-test MEPT.

\section{A. Three Model Teacher Selection}

In this study, the two basic criteria of selecting three model teachers were used, one was high ratings by students, proposed by Hativa, Barak, \& Simhi (2001) and the other was complete concurrence by the supervising administrator, proposed by Strong, Gargani, \& Hacifazlioglu (2011). The evaluation of a particular teacher came from the scores of the Student-Evaluated Teaching Survey (SET), administered by the Academic Office, Chung Yuan Christian University (CYCU) at the end of each semester; and the model teachers in the study obtained high scores for seven years in a row. The selection procedure conducted by the Language Center is described as follows. Seventy-five to eighty 'freshman English' classes are offered every year at the Center of CYCU, and they are differentiated into the "high-intermediate", "intermediate", and "low-beginning" English proficiency levels by the SAT-English test. For each level of classes, one out of 20 to 25 teachers is chosen as the model teacher for the study based on the SET scores documented in the Office of Academic Affairs. Teacher Chang, Teacher Her and Teacher Chen were thus selected as model teachers according to the above-mentioned procedures for three groups of students with "high-intermediate", "intermediate", and "low-beginning" English proficiency levels, respectively. With their consent, the researcher arranged a one-on-one interview with the three model teachers respectively to gather more detailed information on their teaching styles for analysis.

\section{B. Participating Students Selection}

Two hundred ninety-eight students were enrolled across 7 different classes that the three teachers were teaching: three low-beginning level classes taught by Teacher Chang, whose students' SAT-English abilities were at Level 6-8; two intermediate level classes taught by Teacher Her, whose students had SAT-English abilities of Level 10-11, and two high-intermediate level classes taught by Teacher Chen, whose students had SAT-English abilities of Level 12 or above (Level 15 is the highest level for the SAT-English test in Taiwan).

Out of these 298 students, 196 were selected as samples in the following procedures. The students were grouped into 
'high-scoring', 'average-scoring' and 'low-scoring' students based on their final grades from the first semester of the 'Freshman English' course for the 7 classes taught by the three model teachers. In the 7 classes, 8 high-scoring students, 12 average-scoring students, and 8 low-scoring students were randomly selected and were composed as the sampled 196 students.

The selected 19 students were interviewed and the selection of these students was based on their enthusiasm shown in the responses to the questionnaire survey. Of the students, there were 2 high-scoring students, 3 average-scoring students and 1 low-scoring student for each model teacher plus one volunteer student was invited to conduct the 30-35 minute one-on-one interviews.

\section{Analysis of the English Proficiency Improvement of Participating Students}

There are cases that teachers are highly rated by students, but they do not actually learn much from the teachers' professional skills (Young \& Shaw, 1999). Therefore, the pre-MEPT and post-MEPT tests were administered, and the results were compared and analyzed to examine how their learning was going.

\section{Research Tools}

Through the use of the Student Evaluation of Teaching (SET) reports, the implementation of student interviews, teacher interviews, and observations of classroom participants and the comparison of the pre- and post English proficiency tests, the analysis results of the data sets can reveal their teaching effectiveness and, hence, can lend greater impact to the teaching practices (Fenstermacher, 1986).

1. Student evaluation of teaching (SET)

The Academic Office, CYCU, regularly administers a student-evaluated survey of all the courses at the end of each semester; the SET is designed in the form of a Likert scale (1 5), plus open-ended questions designed for students to write comments. The Director of the Center can gain access to all teachers' SET, including average points for each question and all the questions in the evaluation survey and the students' comments.

\section{Student interviews}

Six to seven students from each teacher (total of 19 students) participated in the audio-taped one-on-one interview for 30-35 minutes. The interview questions were: What impresses you most in the course of 'Freshman English'? What does the teacher do that helps you learn? These questions prompted the students to recall what and how they had learned in the class. After all the recordings had been transcribed, the researcher and another experienced teacher went through carefully the transcriptions independently and coded all the ideas which appeared meaningful or valuable in the recalls. Scoring the transcription involved awarding one point to any positive feedback with its meaning.

\section{Teacher interviews}

Each teacher was interviewed by the end of the second semester and all the interviews were transcribed. The interview included questions such as: How do you help your students learn English? The questions helped reveal the pedagogical theories that the teachers used. The interviews were filmed in a very relaxing atmosphere.

\section{Classroom participant observation}

Throughout the four-month class in the second semester, ten hours of each teacher teaching her class were videotaped to record exactly what was said by the teacher and students in the classroom. The videotape was later transcribed. The researcher also attended each teacher's class for two hours. The observations helped the researcher feel and understand the impacts of teaching styles occurring in the classrooms.

\section{Michigan English Placement Test (MEPT)}

MEPT has frequently been used as an assessment tool for the English instructional programs in the U.S. and Canada. The reasons for choosing the MEPT for the study are twofold. Firstly, it is designed to assess English language ability for non-native English-speaking learners who are at the intermediate proficiency level, and it is effective in identifying the English ability level of university non-English major students in Taiwan. Secondly, it has high internal consistency, having reliability coefficients that range from 0.89 to 0.92 (the University of Michigan, English Language Institute, 1994).

\section{AnALYSIS AND RESUlts}

This section presents the analytic results of the collected datasets. The results include a description of three teachers' teaching styles according to the associated pedagogy from the teacher's course syllabi, classroom observation, teacher interviews as well as students' recalls on the learning experiences in practices coded from the interview transcriptions (section 4.1), and the identified teacher qualities observed in the classrooms (section 4.2), In addition, it displays the results of the students' performance in the MEPT pre-test and in the MEPT post-test (section 4.3).

\section{A. Description of Three Teachers' Teaching Styles}

In order to have insight in depth about the teachers' teaching styles, in addition to the teacher interviews, the researcher also took other resources into consideration, such as each teacher's teaching syllabus, and supplementary teaching materials. Based upon the researcher's investigation and review of videotaped teaching sessions, teaching style for each teacher is summarized as follows. 


\section{Teacher Chang's teaching style}

Teacher Chang can be described as a student-centered teacher, focusing on group work and activities approximately $40 \%$ of the time. Since the students in Teacher Chang's classes had relatively lower English ability, she set reachable goals to build student confidence. Teacher Chang also made significant use of Chinese in the classroom, allowing students to use Chinese when giving explanations or completing group work. As for Teacher Chang's pedagogy, she made significant use of the grammar-translation method, giving detailed explanations of the target language and requiring students to do the same in their group activities.

Based on her students' lower English ability and extensive experience with the Taiwanese English education system, Teacher Chang's strategy presumed that students had not developed an affinity towards English learning. This presumption was the basis for her conscious focus on raising student interest in language learning by making good use of group discussion and presentations. Teacher Chang also encouraged students to first seek help from group members as a way to remove the feeling that they were in competition with one another and to build up students' confidence in English learning. Teacher Chang was gentle natured and motherly in her overall style, for example, she would proactively find students who were struggling with an assignment or group activity and not wait for the students to approach her for help.

\section{Teacher Her's teaching style}

Teacher Her, who taught students with relatively modest English ability, adopted a student-centered focus approximately half the time. Teacher Her was more pragmatic in her approach to English, but she frequently varied her teaching activities and presentation formats. Teacher Her's pedagogy was more communicative in nature, holding numerous group and individual in-class activities, and conducting more than three quarters of the class in English, resorting to Chinese only for clarification. Teacher Her demanded this same use of the English language from her students, creating time for students' practice and use of English through reading texts aloud, singing English songs together, and answering questions aloud voluntarily in class, in addition to making group and class presentations. Every student had to be actively involved in the activities, which Teacher Her carefully prepared for each unit she taught. Teacher Her considered establishing good relationships with people to be very important, and encouraged students to open up and to interact with her and one another. Teacher Her kept reminding students to help each other to complete the assigned group work. Teacher Her also spent significant time teaching reading comprehension but also focused on higher order critical thinking skills, encouraging students to try to identify the author's purpose.

Teacher Her was notable for her strict attention to classroom rules, such as not permitting students to eat or sleep in class, requiring students to bring their books to class, and taking attendance immediately after the start of each class. Teacher Her also memorized each student's name, remarkable since her classes were only held once a week, two hours each time. This name recall allowed her to accurately record student participation during each class. Stylistically, Teacher Her dressed formally, treating her class in businesslike fashion, and demanding the same from her students.

\section{Teacher Chen's teaching style}

Teacher Chen, who taught students with relatively higher English ability, adopted a mixed of grammar-translation and task-based teaching methods. Teacher Chen's grammar-translation instruction was applied on the textbook articles, designed for EFL learners. Teacher Chen's task-based method emphasized collaborative learning through group work, such as through the creation of a movie, group translation of a text, or the deconstruction and outlining of a text. These tasks were always modeled first by Teacher Chen or students were given detailed written instructions on how to complete the task, and each task was followed with immediate verbal feedback or written feedback after class. Teacher Chen used the English language approximately 50\% of the time in her classes, resorting to Chinese for detailed explanations, but allowed students to use Chinese unless they were giving their presentations for the assigned activities. Teacher Chen, like Teacher Her, also memorized all her students' names and relied on this knowledge in class.

Teacher Chen's teaching method can be explained by a short description of one activity requiring students to work together to understand essays and stories in the course. In such an activity, students translated the essays and stories into Chinese with help from Teacher Chen. Each student group was assigned a group leader who was responsible for encouraging group members' participation. Upon conclusion of the group activity, group members would be called at random to present the most important vocabulary and to share the main ideas of the target text. In this way, students learned to express their feelings or opinions in English and exercised their skills when they presented their final products to the class.

\section{B. Similarities in Teaching Practices Shared by the Three Teachers}

What qualities in the three teachers can keep students appreciative of their teacher's effort? Table 1 tabulates what they recalled the impressive happenings in their learning environment. T1s3 represents the 3rd student (s3) in Teacher Chang ( $\mathrm{t} 1$ )'s class, and $\mathrm{t} 3 \mathrm{~s} 3$ represents the $3^{\text {rd }}$ student in Teacher Chen ( $\mathrm{t} 3$ )'s class, and so on. Column 2 of Table 1 identifies that all the 19 participating students learned communication skills by getting involved more actively in group work. All the students expressed that they benefited from group discussion, which motivated them to learn more. The English class turned some of their attention from paperwork to more communicative activities, which made the class time more enjoyable and absorbing. It is obviously shown that students were satisfied with their teachers' devotion in lesson preparation, clear instruction, material selection and fair grading, and counted 11 times for Teacher Chang, 11 times for Teacher Her and 10 times for Teacher Chen. To summarize, the teachers received 32 points from the 
fundamental expectations of the students and 22 points from making extra effort and time to help students with forming good attitude or study habit, assignment check, and outside class e-mail communication between teacher and student. However, the greatest points of 46 were about the stimulative, lively and innovative classroom atmosphere.

TABLE 1.

IDENTIFIED TEACHER QUALITIES FROM STUDENT INTERVIEW TRANSCRIPTION SCORING

\begin{tabular}{|c|c|c|c|c|c|c|}
\hline & & $\begin{array}{l}\text { Teacher Chang } \\
(\text { Teacher } 1: \mathrm{t} 1) \\
\end{array}$ & $\begin{array}{l}\text { Teacher Her } \\
(\text { Teacher 2: } \mathrm{t} 2)\end{array}$ & $\begin{array}{l}\text { Teacher Chen } \\
(\text { Teacher } 3: \mathrm{t} 3)\end{array}$ & $\begin{array}{l}\text { Total } \\
\text { Count }\end{array}$ & Notes \\
\hline \multirow[t]{5}{*}{$\begin{array}{l}\text { Teacher's } \\
\text { investment }\end{array}$} & Well-prepared class & $\begin{array}{l}1 \\
\text { t1s } 7 \\
\end{array}$ & $\begin{array}{l}2 \\
\mathrm{t} 2 \mathrm{~s} 5, \mathrm{t} 2 \mathrm{~s} 6 \\
\end{array}$ & $\begin{array}{l}2 \\
\mathrm{t} 3 \mathrm{~s} 1, \mathrm{t} 3 \mathrm{~s} 3\end{array}$ & 5 & \\
\hline & $\begin{array}{l}\text { Clear teaching } \\
\text { instruction }\end{array}$ & & $\begin{array}{l}3 \\
\mathrm{t} 2 \mathrm{~s} 1, \mathrm{t} 2 \mathrm{~s} 4, \mathrm{t} 2 \mathrm{~s} 6 \\
\end{array}$ & $\begin{array}{l}1 \\
\mathrm{t} 3 \mathrm{~s} 1 \\
\end{array}$ & 4 & \\
\hline & $\begin{array}{l}\text { Course material } \\
\text { matches student's } \\
\text { skill level }\end{array}$ & $\begin{array}{l}3 \\
\mathrm{t} 1 \mathrm{~s} 4, \mathrm{t} 1 \mathrm{~s} 5, \mathrm{t} 1 \mathrm{~s} 7\end{array}$ & $\begin{array}{l}2 \\
\mathrm{t} 2 \mathrm{~s} 1, \mathrm{t} 2 \mathrm{~s} 2\end{array}$ & $\begin{array}{l}2 \\
\mathrm{t} 3 \mathrm{~s} 1, \mathrm{t} 3 \mathrm{~s} 4\end{array}$ & 7 & \\
\hline & Fair grading criteria & $\begin{array}{l}7 \\
\mathrm{t} 1 \mathrm{~s} 1, \mathrm{t} 1 \mathrm{~s} 2,1 \mathrm{~s} 3 \\
\mathrm{t} 1 \mathrm{~s} 4, \mathrm{t} 1 \mathrm{~s} 5, \mathrm{t} 1 \mathrm{~s} 6, \\
\mathrm{t} 1 \mathrm{~s} 7\end{array}$ & $\begin{array}{l}4 \\
\mathrm{t} 2 \mathrm{~s} 1, \mathrm{t} 2 \mathrm{~s} 2, \mathrm{t} 2 \mathrm{~s} 4, \mathrm{t} 2 \mathrm{~s} 5\end{array}$ & $\begin{array}{l}5 \\
\mathrm{t} 3 \mathrm{~s} 1, \mathrm{t} 3 \mathrm{~s} 2, \mathrm{t} 3 \mathrm{~s} 3 \\
\mathrm{t} 3 \mathrm{~s} 4, \mathrm{t} 3 \mathrm{~s} 5\end{array}$ & 16 & $\begin{array}{l}\text { Students care about } \\
\text { their grades. }\end{array}$ \\
\hline & & 11 & 11 & 10 & 32 & \\
\hline \multirow{5}{*}{$\begin{array}{l}\text { Teacher's extra } \\
\text { effort for } \\
\text { personal } \\
\text { emotional } \\
\text { investment }\end{array}$} & $\begin{array}{l}\text { Demand good } \\
\text { learning attitude }\end{array}$ & $\begin{array}{l}2 \\
\mathrm{t} 3 \mathrm{~s} 1, \mathrm{t} 1 \mathrm{~s} 4, \mathrm{t} 3 \mathrm{~s} 7\end{array}$ & $\begin{array}{l}2 \\
\mathrm{t} 2 \mathrm{~s} 1, \mathrm{t} 2 \mathrm{~s} 2 \\
\end{array}$ & $\begin{array}{l}1 \\
\mathrm{t} 3 \mathrm{~s} 1 \\
\end{array}$ & 5 & \\
\hline & $\begin{array}{l}\text { Assign outside class } \\
\text { readers }\end{array}$ & $\begin{array}{l}4 \\
\mathrm{t} 1 \mathrm{~s} 1, \mathrm{t} 1 \mathrm{~s} 5, \mathrm{t} 1 \mathrm{~s} 6, \\
\mathrm{t} 1 \mathrm{~s} 7\end{array}$ & $\begin{array}{l}5 \\
\mathrm{t} 2 \mathrm{~s} 1, \mathrm{t} 2 \mathrm{~s} 2, \mathrm{t} 2 \mathrm{~s} 3 \\
\mathrm{t} 2 \mathrm{~s} 4, \mathrm{t} 2 \mathrm{~s} 6\end{array}$ & $\begin{array}{l}2 \\
\mathrm{t} 2 \mathrm{~s} 4, \mathrm{t} 2 \mathrm{~s} 5\end{array}$ & 11 & $\begin{array}{l}11 \text { of } 19 \text { students } \\
\text { love the assigned } \\
\text { outside reader. }\end{array}$ \\
\hline & $\begin{array}{l}\text { Check students' } \\
\text { assignments } \\
\text { regularly }\end{array}$ & $\begin{array}{l}1 \\
\mathrm{t} 1 \mathrm{~s} 7\end{array}$ & $\begin{array}{l}4 \\
\mathrm{t} 2 \mathrm{~s} 1, \mathrm{t} 2 \mathrm{~s} 2, \mathrm{t} 2 \mathrm{~s} 4, \mathrm{t} 2 \mathrm{~s} 6\end{array}$ & & 5 & $\begin{array}{l}5 \text { students believe } \\
\text { that homework is } \\
\text { necessary. }\end{array}$ \\
\hline & $\begin{array}{l}\text { Welcome questions } \\
\text { via e-mail }\end{array}$ & & & $\begin{array}{l}1 \\
\mathrm{t} 2 \mathrm{~s} 1\end{array}$ & 1 & \\
\hline & & 7 & 11 & 4 & 22 & \\
\hline \multirow[t]{5}{*}{$\begin{array}{l}\text { Stimulation and } \\
\text { innovation in } \\
\text { the classrooms }\end{array}$} & $\begin{array}{l}\text { Collaborative work } \\
\text { through group } \\
\text { discussion and } \\
\text { presentation }\end{array}$ & $\begin{array}{l}7 \\
\text { t1s1,t1s2,t1s3, } \\
\text { t1s4,t1s5, t1s6, } \\
\text { t1s7 }\end{array}$ & $\begin{array}{l}6 \\
\mathrm{t} 2 \mathrm{~s} 1, \mathrm{t} 2 \mathrm{~s} 2, \mathrm{t} 2 \mathrm{~s} 3, \\
\mathrm{t} 2 \mathrm{~s} 4, \mathrm{t} 2 \mathrm{~s} 5, \mathrm{t} 2 \mathrm{~s} 6\end{array}$ & $\begin{array}{l}6 \\
\mathrm{t} 3 \mathrm{~s} 1, \mathrm{t} 3 \mathrm{~s} 2, \mathrm{t} 3 \mathrm{~s} 3 \\
\mathrm{t} 3 \mathrm{~s} 4, \mathrm{t} 3 \mathrm{~s} 5, \mathrm{t} 3 \mathrm{~s} 6\end{array}$ & 19 & \\
\hline & $\begin{array}{l}\text { Lively and } \\
\text { innovative class }\end{array}$ & $\begin{array}{l}5 \\
\mathrm{t} 1 \mathrm{~s} 1, \mathrm{t} 1 \mathrm{~s} 2, \mathrm{t} 1 \mathrm{~s} 4, \\
\mathrm{t} 1 \mathrm{~s} 5, \mathrm{t} 1 \mathrm{~s} 6\end{array}$ & $\begin{array}{l}5 \\
\mathrm{t} 2 \mathrm{~s} 1, \mathrm{t} 2 \mathrm{~s} 3, \mathrm{t} 2 \mathrm{~s} 4, \\
\mathrm{t} 2 \mathrm{~s} 5, \mathrm{t} 2 \mathrm{~s} 6\end{array}$ & $\begin{array}{l}4 \\
\mathrm{t} 2 \mathrm{~s} 3, \mathrm{t} 2 \mathrm{~s} 4, \mathrm{t} 2 \mathrm{~s} 5, \mathrm{t} 2 \mathrm{~s} 6\end{array}$ & 14 & \\
\hline & $\begin{array}{l}\text { Constant } \\
\text { encouragement by } \\
\text { teachers }\end{array}$ & $\begin{array}{l}4 \\
\mathrm{t} 1 \mathrm{~s} 1, \mathrm{t} 1 \mathrm{~s} 4, \mathrm{t} 1 \mathrm{~s} 5, \\
\mathrm{t} 1 \mathrm{~s} 7\end{array}$ & $\begin{array}{l}5 \\
\mathrm{t} 2 \mathrm{~s} 2, \mathrm{t} 2 \mathrm{~s} 3, \mathrm{t} 2 \mathrm{~s} 4, \\
\mathrm{t} 2 \mathrm{~s} 5, \mathrm{t} 2 \mathrm{~s} 6\end{array}$ & $\begin{array}{l}2 \\
\mathrm{t} 3 \mathrm{~s} 2, \mathrm{t} 3 \mathrm{~s} 5\end{array}$ & 11 & \\
\hline & $\begin{array}{l}\text { Share their own } \\
\text { English learning } \\
\text { experiences }\end{array}$ & $\begin{array}{l}1 \\
\mathrm{t} 1 \mathrm{~s} 7\end{array}$ & & $\begin{array}{l}1 \\
\mathrm{t} 3 \mathrm{~s} 3\end{array}$ & 2 & \\
\hline & & 17 & 16 & 13 & 46 & \\
\hline Total & & 35 & 38 & 27 & 100 & \\
\hline
\end{tabular}

\section{Students'Learning Achievement Based on Their Performance in the MEPT Post-test}

There are cases that teachers are highly rated by students but they do not actually learn much from the teachers' professionism (Young \& Shaw, 1999). It was a confirmation to find through the paired t-tests that students of all three teachers had made statistically significant improvement in overall performance over the four months of work in the second semester, as seen in Table 2. Specifically, students taught by Teacher Chang showed significant improvement in reading; students taught by Teacher Her showed significant improvement in listening, grammar, and vocabulary; students taught by Teacher Chen showed significant improvement in listening and vocabulary. These results are meaningful considering each class involved in this study met only for two hours, once per week. 
TABLE 2.

RESUlTS OF PAIRED T-TESTS FOR THE THREE TEACHERS' CLASSES

\begin{tabular}{|c|c|c|c|c|c|}
\hline & Teacher & p-value & $\begin{array}{l}\text { Mean score } \\
\text { Before }\end{array}$ & $\begin{array}{l}\text { Mean score } \\
\text { after }\end{array}$ & Sample size \\
\hline \multirow{3}{*}{ Listening } & Chang & 0.51 & 8.86 & 8.66 & 90 \\
\hline & Her & $0.015^{\mathrm{a}}$ & 10.04 & 11.09 & 75 \\
\hline & Chen & $0.012^{\mathrm{a}}$ & 10.4 & 11.21 & 73 \\
\hline \multirow{3}{*}{ Grammar } & Chang & 0.55 & 17.88 & 17.64 & 90 \\
\hline & Her & $0.004^{\mathrm{a}}$ & 20.09 & 21.17 & 75 \\
\hline & Chen & 0.18 & 21.88 & 22.33 & 73 \\
\hline \multirow{3}{*}{ Vocabulary } & Chang & 0.53 & 15.59 & 15.81 & 90 \\
\hline & Her & $0.09^{\mathrm{b}}$ & 19.92 & 20.52 & 75 \\
\hline & Chen & $0.0002^{\mathrm{a}}$ & 20.71 & 21.89 & 73 \\
\hline \multirow{3}{*}{ Reading } & Chang & $0.001^{\mathrm{a}}$ & 7.98 & 10.13 & 90 \\
\hline & Her & 0.23 & 11.31 & 10.79 & 75 \\
\hline & Chen & 0.57 & 12.67 & 12.49 & 73 \\
\hline \multirow{3}{*}{$\begin{array}{l}\text { Overall } \\
\text { Improvement }\end{array}$} & Chang & $0.08^{\mathrm{b}}$ & 50.3 & 52.24 & 90 \\
\hline & Her & $0.0158^{\mathrm{a}}$ & 61.36 & 63.57 & 75 \\
\hline & Chen & $0.0008^{\mathrm{a}}$ & 65.66 & 67.92 & 73 \\
\hline
\end{tabular}

\section{DISCUSSION}

The purpose of this research is to determine what common qualities these successful teachers share. One thing that comes quickly into view when analyzing the students' reactions to their teachers' teaching is that part of the way they evaluate teaching quality is based on the way that they "feel". This corresponds with what Benson (1996) described as "subjective needs" and Aulls' (2004) finding that students emphasize emotions more than academic learning outcomes when assessing teacher quality. The result of this study also mirrors Allan, Clarke, and Jopling's (2009) finding that students have the fewest divergent opinions about the value of a teacher's excellent subject knowledge, information relevancy, patience, respect, and enthusiasm.

One of the contributing factors for the successful teaching was likely attributed to the supportive interaction between the students, but such a learning environment is not a typical one in Taiwan. Therefore it is important to look at what the teachers have done in order to allow for it to come about. Teacher Her mentioned that she is "strict with [herself] in preparing lessons and choosing teaching materials based on students' interest". This comment right away reveals the fact that Teacher Her recognizes that "students' interests" are perhaps more important than anything else when it comes to material selection, which is consistent with Benson's (1996) suggested approach and, interestingly enough, Noddings' care ethic, which focuses on listening to students' concerns (2002). Were this not the case she might have indicated that she chose material based on considerations of practicality or students' needs first. Teacher Chen expresses even more evidence of efforts made towards developing an environment where a certain amount of emotional stimulation takes place. She states: I choose materials based on their interest. I am concerned about how they learn and what they feel. I like to encourage them, avoid placing them in an embarrassing situation. This statement is evidence of a teacher who shows clear sensitivity towards the way in which the students "feel". Not only is there common emphasis given towards the interests of the students, but also, Teacher Chen takes things a step further and tries to put herself in the emotional shoes of her students when she coordinates classroom activities. This practice is also shared by Teacher Chang who expressed her sensitivity towards the students' emotions when she told of how "one of the course objectives is to remove their fear of their English learning." This comment reveals the fact that Teacher Chang believes that if she hopes to improve the performance results of her students, there are emotional factors that must be taken into consideration. This process clearly embodies Noddings' (2002) ethic of care which requires the caring teacher to listen to students to gain a better understanding of their feelings and situation. In sum, all three teachers have taken action in one form or another to step inside their students' shoes in hopes of meeting needs that may be described as "personal" rather than "academic" and also subjective rather than objective.

The first common "feeling" that the students of all classes shared could be described as "stimulated". That is to say the students were not indifferent with respect to what was taking place. This comment parallels Hativa, Barak, and Simhi's (2001) finding that exemplary teachers are interesting and engaging. The importance of classroom activities for Taiwanese students specifically was also reported by Chu and Huang (2007). The students of Teacher Her's class perhaps said it most candidly when they noted that "all the students are kept awake in class". This comment implies, first of all, that there is at least some level of innovation to a class in which all the students remain awake throughout. If the students are to make such a comment, it means that the teacher has done something different that has prevented students from having the opportunity or desire to nap during class time.

As with Teacher Her's students, the students of Teacher Chang also recognized a unique and more stimulating atmosphere in which they had been participating. They reflected on their experience saying, "we learned to listen to others, rather than the teacher only; we learned to discuss and express ourselves and to interact among group members 
and between the teacher and students". This added involvement and new sense of personal contribution is without a doubt going to allow the students to maintain a higher level of stimulation during class, and also help the students feel as though they have a personal investment in the way things turn out. This desire for group work and cooperation is reflected in Chu and Huang's survey of 54 Taiwanese vocational college English learners (2007), as well as Allan, Clarke, and Jopling's 2009 survey of British university students.

A comment made by the students of Teacher Chen's class also indicates a certain level of stimulation taking placeyet it might not be in the form that one might expect. In reaction to a task that Teacher Chen asked her students to perform, the students said about themselves: "we were upset at the beginning, but we felt so proud of ourselves when we finished." Such a response demonstrates that the students clearly have a certain level of emotional investment that they have made in the task that they were presented with. This reveals that stimulation and emotional investment are present in classrooms where the students show improvement and feel as though they have gained something. Another important observation is the fact that they referred to themselves in the plural ("we felt proud") rather than singular, which is further evidence of the "sink or swim together" mentality described by Johnson, Johnson \& Smith (1995).

Additionally the interaction, communication, cooperation, joint hardship, inter-group competition, and group pride that resulted from the assigned tasks led to cohesive group work and made the students more willing to personally and emotionally invest in the outcome of the class which was consistent with what Johnson et al. (1995) described as the 'sink or swim together' mentality. So, what kinds of emotional reactions might be found in a learning environment that produces the kind of results that teachers are hoping to attain? By examining the comments that students made in this study, some insight can be gained.

One way the researcher can see that a certain level of stimulation was maintained was because the students also took action to encourage one another. The students mentioned that they had "[learned] to encourage each other to complete the task together". In such a setting it goes without saying that the students are going to be more energized and willing to complete the task at hand which the teacher has provided. This is consistent with Millis \& Rhem's (2010) description of an effective language learning environment. As the students encourage each other or as Teacher Her's students described, "help each other to accomplish the assigned task", the feelings of acceptance and significance that a student has are going to be elevated and they will be more willing to try, and less fearful of making mistakes.

In addition to the emotional considerations, there are also those that could be classified as "stimulative". As seen above, the students of all different English ability classes described how they had found themselves in situations which were relatively new experiences for them and they were required to engage in activities that called for higher level of participation - both physical and mental. This was not without its design, as all three teachers explicitly expressed the fact that they intended to create an atmosphere unlike the traditional teaching environment, in which students need to take more responsibility for their learning. In this way their approach also involved what Tudor (1996) described as the central factor in learner-centered teaching.

If perhaps, the students are exposed to a similar type of classroom setting for an extended period of time, can the same elevated level of results be expected or will they disappear along with the feeling of innovation? If it is the case that the factor of innovation turns out to be the more significant one, this means that teachers will have to work towards constantly reinventing the classroom experience in order to maintain a consistent level of achievement. In other words, other steps will have to be taken in order to maintain that feeling of novelty to continue on over a longer stretch of time.

In short, from the information collected from the three teachers' classrooms via student and teacher interviews, evidence was found of three commonalities which include "emotional investment", "stimulation", and "innovation". These three factors helped to create a learning environment where the students were able to enjoy their learning experience and simultaneously achieve tangible results.

\section{CONCLUSION AND PEDAGOgiCAl APPLiCATION}

It is admirable that these three teachers have been highly appraised by the students' evaluation reports for years and they have consistently been rated as "outstanding" by students. Based on what students stated in interviews, after the one-year course, they could read English faster, read longer texts, and could understand class lectures. During interviews students expressed the fact that they felt as though they were actually making real progress as a result of their classes and this progress was substantiated by the results of the MEPT post-test. Regarding learning achievement, the paired t-test, as shown in Table 2, indicates that the students have made statistically significant English improvement in the overall performance between the pre-test and the post test. To sum up, all of the factors mentioned above contributed to creating an environment that had a certain uniqueness and novelty to it which inspired students and kept up the levels of interest and participation.

What was of greatest value to the researcher was allowed by the university and the teachers to have the access to the participating students' evaluation documents, the sampled learners themselves and the three exemplary teachers. The study has highlighted some similarities in the teaching styles used by these three teachers which might be utilized as a model for other teachers of English as a foreign language or a variety of other courses. The three main underlying factors which were most prominent were emotionally invested, the stimulated and innovative nature of each of the learning environments as experienced by the students. One thing was constant for all three teachers and that is that they were leading their students to be more responsible for their own learning and encouraging more interaction between the 
teacher and students. Overall this study revealed the importance of trying to gain an understanding of both the academic needs of the students (those pertaining to language acquisition) as well as the personal or emotional needs. This was done by recognizing the fact that students may be experiencing feelings of embarrassment or inadequacy and therefore require teaching methods that diminish those feelings rather than emphasize them.

Furthermore, as suggested earlier, there was no reason to expect that the results of this study would be limited to language learning environments and after reviewing the data it would appear that the assumption was confirmed to be accurate. The main elements (emotional investment, innovation, and stimulating environment) that were consistent in the classrooms of the three teachers who acted as subjects for this study should be elements that have universal applicability when it comes to learning. The teachers in this study made use of cooperative learning techniques, by allowing the students to get involved and take on responsibility of their own rather than using traditional lecture-style techniques. With a little imagination, such techniques could be applied to many types of classroom settings. Furthermore, if the teacher is able to devise other ways to help incorporate the elements mentioned above into their classrooms it is likely that student performances would show signs of improvement.

\section{ACKNOWLEDGMENT}

The author wishes to thank Dr. Laura Wang of the Language Center, Chung Yuan Christian University, for her full support of the study and Dr. Margaretha Hsu, Shippensburg University, USA for the statistical analysis. Also a special thanks to my research assistant Nicholas Van Heyst for support in the interview analysis. This work was supported by the National Science Council, Taiwan, ROC [grant number NSC 99-2410-H-033-052].

\section{REFERENCES}

[1] Allan, J., Clarke, K., \& Jopling, M. (2009). Effective teaching in higher education: perceptions of first year undergraduate students. International Journal of Teaching and Learning in Higher Education, 21(3), 362-372.

[2] Aulls, M. W. (2004). Students' experiences with good and poor university courses. Educational Research and Evaluation, 10(4-6), 303-335.

[3] Bain, K. (2004). What the Best College Teachers Do. Cambridge, Massachusetts: Harvard University Press.

[4] Benson, P. (1996). Concepts of autonomy in language learning. In R. Pemberton \& E. Li (Eds.), Taking control: Autonomy in language learning (pp. 27-34). Hong Kong: Hong Kong University Press.

[5] Brown, H. D. (2007). Teaching by principles: An interactive approach to language pedagogy ( $3^{\text {rd }}$ ed.). White Plains, NY: Pearson Education.

[6] Chia, H. U., Johnson, R., Chia, H. L., \& Olive, F. (1999). English for college students in Taiwan: A study of perceptions of English needs in a medical context. English for Specific Purposes 18(2), 107-119.

[7] Chien, C. N. (2008). Expectations of English courses for non-English university majors in an EFL context, presented at Association for Language Awareness 9th International Conference on Engaging with Language, p. 53, University of Hong Kong, Hong Kong, China, June 26 29, 2008.

[8] Cohen, A. D. \& Weaver, S. J. (2005). A teachers' guide to styles- and strategies-based instruction. Revised version of CARLA working paper series \#7. Minneapolis, MN: Center for Advanced Research for Language Acquisition.

[9] Chu, S. C., \& Huang, C. H. (2007). Meeting college students' learning expectations. Paper presented at the Sixteenth International Symposium on English Teaching, ETA/ROC (pp. 78-85). Taipei: Crane Publishing Co., LTD.

[10] Fenstermacher, G (1986). Philosophy of research on teaching: Three aspects. In M. Wittrock (Ed.), Handbook of research on teaching (3rd ed., pp 37-49). New York: Macmillan.

[11] Gunderson, B., \& Johnson, D. (1980). Building positive attitudes by using cooperative learning groups. Foreign Language Annals, 13(1), 39-43.

[12] Hativa, N., Barak, R., \& Simhi, E. (2001). Exemplary university teachers: Knowledge and beliefs regarding effective teaching dimensions and strategies. The Journal of Higher Education, 72(6), 699-729.

[13] Hsieh, C. N. (2010). Ideology and Challenges: Overview of English curriculum at Ming Chuan University. Paper presented at the $4^{\text {th }}$ Conference on College English (pp. 4-5). National Chengchi University, Taipei.

[14] Hsieh, Y. L., \& Wu, Y. H. (1988). A need analysis for the curriculum and syllabus of freshman English at Tsinghua University. Paper presented at the Fifth Conference on English Teaching and Learning in the Republic of China (pp. 227-243). Taipei: The Crane Publishing Co., Ltd.

[15] Johnson, D. W., Johnson, R. T., \& Smith, K. A. (1995). Cooperative learning and individual student achievement in secondary schools. In J. E. Pedersen \& A. D. Digby (Eds.), Secondary schools and cooperative learning: Theories, models, and strategies (pp. 3-54). New York: Garland.

[16] Knight, S. L., \& Waxman, H. C. (1991). Analyzing effective teaching of Hispanic students' problem-solving strategies in Spanish. NABE Annual Conference Journal, 1988-1989. Washington, DC: National Association for Bilingual Education.

[17] Kuo, C. (1987). A needs study of undergraduate and graduate EST students and in-service technical professionals. Paper presented at the Fourth Conference on English Teaching and Learning in the Republic of China (pp. 263-274). Taipei: Crane Publishing Co., LTD.

[18] Kuo, C. H. (1990a). The designing of the college English courses. English Teaching and Learning. 15(1), 44-51.

[19] Kuo, C. H. (1990b). The designing of the college English courses. English Teaching and Learning. 15(2), 77-84.

[20] Kuo, C. H., Hung, C. L., Chang, T. S., \& Chang, Y. L. (1990). The designing of the college English courses. English Teaching and Learning. 15(1), 44-51.

[21] Kuo, C. H., Hung, C. L., Chang, T. S., \& Chang, Y. L. (1990). The designing of the college English courses. English Teaching and Learning. 15(2), 77-84. 
[22] Lee, J. Y. (2011). Moving towards a more balanced English teaching: A case from Taiwanese EFL classrooms. English Language Teaching, 4(2), 132-137.

[23] Lo, Z. H. (2005). The serious academic gap between high- and low-achieving English learners on the Joint College of Entrance Examination: Educators worry. Retrieved July 12, 2005, from http://www.wfdn.com.tw/9403/050306/01-08/030603-1.htm.

[24] Magno, C., \& Sembrano, J. (2007). The role of teacher efficacy and characteristics on teaching effectiveness, performance, and use of learner-centered practices. The Asia-Pacific Education Researcher, 16(1), 73-90.

[25] Millis, B. J. \& Rhem, J. (2010). Cooperative learning in higher education: Across the disciplines. Stylus Publishing, LLC.

[26] Noddings, N. (2002). Educating moral people: A caring alternative to character education. Williston, VT: Teachers College Press.

[27] O'Malley, J. M., \& Chamot, A. U. (1990). Learning strategies in second language acquisition. Cambridge: Cambridge University Press.

[28] Oxford, R. (2003). Language learning styles and strategies: Concepts and relationships. IRAL: International Review of Applied Lnguistics in Language Teaching, 41(4), 271-278.

[29] San, H. Y. (2005, February 26). To raise the score of zero, eliminate multiple choice questions and institute an essay answer. Retrieved from http://www.libertytimes.com.tw/2005/new/feb/26/today-life1.htm.

[30] Strong, M., Gargani, J., \& Hacifazlioglu, O. (2011). Do we know a successful teacher when we see one? Experiments in the identification of effective teachers. Journal of Teacher Education, 62(4), 367-382.

[31] Tuan, H. L., Chang, H. P., Wang, K. H. \& Treagust, D. F. (2000). The development of an instrument for assessing students' perceptions of teachers' knowledge. International Journal of Science Education, 22(4), 385-398.

[32] Tudor, I. (1996). Learner-centeredness as language education. Cambridge: Cambridge University Press.

[33] Wang, F. (2009, March 15). Teachers lament poor scores in English. Taipei Times. Retrieved from http://www.taipeitimes.com/news/taiwan/print/2009/03/15/2003438532.

[34] Wang, F. (2010, February 25). More than $10 \%$ of students score no points in English. Taipei Times. Retrieved from http://www.taipeitimes.com/news/taiwan/print/2010/02/25/2003466583.

[35] Wang, Y. C. (2003). Communication-orientation in Freshman English curriculum: A new response. Selected papers from the Twelfth International Symposium on English Teaching (pp. 589-598). Taipei: Crane Publishing Co., LTD.

[36] Yang, Y. L. (1985). Suggestions on reforming the freshman English instruction. The National Cheng Chi University Journal, 51, 167-184.

[37] Young, S., \& Shaw, D. G. (1999). Profiles of effective college and university teachers. The Journal of Higher Education, 70(6), 670-686.

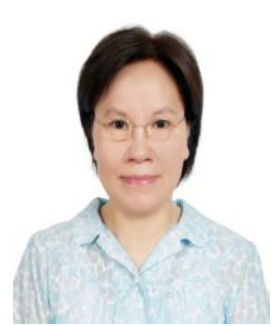

Ching-ning Chien is an associate Professor of Applied Linguistics at Chung Yuan Christian University (CYCU), Taiwan, where she teaches listening, speaking and reading to freshman and sophomore students. She earned her two M.A. degrees in special education from Tennessee Technological University in 1968 and in English education from the Ohio State University in 1985 and received her Ph.D. in education from the University of Newcastle upon Tyne, England in 1998. She was the chairperson of the Department of Applied Linguistics and Language Studies and the Director of the Language Center, CYCU, respectively, for many years.

Amongst her publications are A case study of an ESP-integrated EFL curriculum for Taiwan university students, The International Journal of Pedagogy and Curriculum, 2013; Needs-based analyses of Freshman English courses in a Taiwan university, International Journal of Humanities and Social Science, 2011, and The role of phonological awareness development in young Chinese EFL learners, Language Awareness, 2008. Her current work focuses on English listening comprehension, English for specific purposes (ESP) and teacher education. 